\title{
Proses berpikir siswa dalam menyelesaikan masalah geometri: Perbedaan siswa bertemperamen choleric dengan melancholic
}

\section{Miftah Syarifuddin ${ }^{1}$}

\begin{abstract}
Abstrak: Penelitian ini bertujuan untuk mendeskripsikan proses berpikir siswa bertemperamen choleric dan melancholic dalam menyelesaikan masalah geometri. Proses berpikir dalam penelitian ini adalah proses berpikir konseptual atau proses berpikir prosedural. Proses berpikir konseptual meliputi 5 (lima) kompetensi, yaitu menggunakan aturan dasar, melihat pola, menerapkan konsep, mengklarifikasi situasi, dan mengembangkan masalah. Proses berpikir prosedural adalah cara berpikir siswa yang terbiasa menghafal rumus dan menggunakan cara-cara rutin dalam menyelesaikan masalah. Penelitian ini merupakan penelitian deskriptif dengan pendekatan kualitatif. Subjek penelitian terdiri dari 2 (dua) siswa perempuan dengan kemampuan matematika tinggi dan setara di kelas IX Salatiga, Indonesia, terdiri dari 1 (satu) siswa bertemperamen choleric dan 1 (satu) siswa bertemperamen melancholic. Pemilihan subjek penelitian berdasarkan hasil tes temperamen dan hasil tes kemampuan matematika. Data penelitian diperoleh dari pemberian tugas penyelesaian masalah geometri dan wawancara kepada para subjek penelitian sebanyak 2 (dua) kali. Pemberian tugas penyelesaian masalah kedua dan wawancara kedua merupakan triangulasi data. Hasil penelitian menunjukkan bahwa proses berpikir siswa terungkap melalui tugas penyelesaian masalah geometri yang diberikan. Siswa bertemperamen choleric menggunakan proses berpikir prosedural dalam menyelesaikan masalah geometri, sedangkan siswa bertemperamen melancholic menggunakan proses berpikir konseptual dalam menyelesaikan masalah geometri.
\end{abstract}

Kata kunci: Proses Berpikir; Choleric; Melancholic; Masalah Geometri

Abstract: This study aims to describe the thinking process of students
with choleric and melancholic temperament in solving geometry
problems. The thinking process in this research is conceptual thinking
process or procedural thinking process. The conceptual thinking
process includes 5 (five) competencies, i.e. using basic rules, seing
patterns, applying concepts, clarifying situations, and developing
problems. The process of procedural thinking is a way of thinking of
students who are used to memorizing formulas and using routine ways

${ }^{1}$ MTs Negeri Salatiga, Indonesia, miftahsyarifuddin24031978@gmail.com 
of solving problems. This research was a descriptive research with qualitative approach. The subjects consisted of 2 (two) female students with high and equivalent mathematics abilities in the ninth grade in Salatiga, Indonesia consisting of 1 (one) choleric student and 1 (one) melancholic student. The selection of research subjects is based on temperament test and mathematical ability test. Research data obtained from geometry problem solving task and interview to the research subjects twice. The second task of problem solving and interview is triangulation of data. The results reveal the thinking process of students through the task of solving the geometry problem given. Student with choleric temperament used procedural thinking processes in solving geometry problems, while student with melancholic temperament used conceptual thinking processes in solving geometry problems.

Keywords: Thinking; Choleric; Melancholic; Geometry Problems

\section{A. Pendahuluan}

Berpikir merupakan salah satu proses yang alamiah (Duron, Limbach, \& Waugh, 2006). Tetapi, jika aktivitas tersebut tidak terarah, maka akan menjadi bias atau menyimpang, distorsi (bertolak belakang dengan fakta atau aturan), kurangnya informasi, dan berpotensi menjadi sebuah prasangka (Duron $d k k, 2006$ ). Dengan demikian, berpikir harus diarahkan dengan baik agar menghasilkan buah pikiran yang baik pula. Pikiran dapat diartikan sebagai kondisi hubungan antar bagian pengetahuan yang telah ada dalam diri dan dikontrol oleh akal. Akal berperan sebagai kekuatan yang mengendalikan pikiran. Hal ini berarti bahwa dengan berpikir manusia akan memperoleh pengetahuan.

Berpikir konseptual dibagi menjadi 5 (lima) kompetensi perilaku, yaitu menggunakan aturan dasar, melihat pola, menerapkan konsep, menjelaskan kondisi, dan menciptakan konsep baru (Abdillah, 2007; Government of Canada, 2015), sedangkan berpikir prosedural adalah cara berpikir siswa yang terbiasa menghafal rumus dan menggunakan caracara rutin yang biasa digunakan dalam menyelesaikan soal matematika (Hamda, 2016).

Masalah dianggap sebagai latihan yang memerlukan keterampilan komputasi dasar untuk menyelesaikannya dalam mata pelajaran matematika (Avcu \& Avcu, 2010). Beberapa teori menganggap 
penyelesaian masalah menjadi proses kunci dalam pembelajaran, terutama dalam domain seperti sains dan matematika (Schunk, 2012). Penyelesaian masalah dalam matematika mempunyai peranan penting dalam keberhasilan pembelajaran. Hal ini sesuai dengan Peraturan Menteri Pendidikan dan Kebudayaan Republik Indonesia Nomor 68 Tahun 2013 (Kementerian Pendidikan dan Kebudayaan Republik Indonesia, 2013) di mana salah satu kompetensi dasar jenjang Sekolah Menegah Pertama/Madrasah Tsanawiyah adalah menunjukkan sikap logis, kritis, analitik, konsisten dan teliti, bertanggung jawab, responsif, dan tidak mudah menyerah dalam menyelesaikan masalah. Hal ini menunjukkan bahwa setiap siswa dituntut untuk memiliki kemampuan dalam menyelesaikan masalah matematika yang dihadapinya.

Masalah ruang dan bentuk dipelajari dalam salah satu cabang matematika yang disebut dengan geometri. Geometri adalah salah satu cabang yang paling penting dari pendidikan matematika, karena tujuan pembelajaran geometri adalah untuk memberikan siswa kemampuan berpikir kritis, penyelesaian masalah, dan pemahaman yang lebih baik dari materi lain dalam matematika dengan membuat siswa memiliki keterampilan berpikir geometris tingkat tinggi (Aydogdu \& Kesan, 2014).

Penelitian tentang geometri menemukan bahwa siswa kurang akurat dalam mengidentifikasi segitiga (60\% benar) dan persegipanjang $(54 \%$ benar) (Clements \& Sarama, 2000). Hal lain dapat dilihat pada daya serap materi bangun datar Ujian Nasional Matematika untuk tingkat Sekolah Menengah Pertama/Madrasah Tsanawiyah. Pusat Penilaian Pendidikan mengeluarkan analisisnya dalam Laporan Hasil Ujian Nasional yang salah satunya menunjukkan persentase daya serap atau penguasaan materi mata pelajaran yang diujikan. Penguasaan materi bangun datar secara nasional menunjukkan bahwa kemampuan menyelesaikan masalah yang berkaitan dengan luas bangun datar pada tahun pelajaran 2012/2013 sebesar 47,93\%, tahun pelajaran 2013/2014 sebesar 72,85\%, dan tahun pelajaran 2014/2015 sebesar 46,21\%. Kemampuan menyelesaikan masalah yang berkaitan dengan keliling bangun datar pada tahun pelajaran 2012/2013 sebesar 60,14\%, tahun pelajaran 2013/2014 sebesar 55,23\%, dan tahun pelajaran 2014/2015 sebesar 59,98\% (Pusat Penilain Pendidikan Republik Indonesia, 2015). Berdasarkan data tersebut, dapat 
disimpulkan bahwa daya serap atau penguasaan siswa pada materi geometri, khususnya bangun datar masih perlu ditingkatkan.

Perbedaan proses berpikir yang dilakukan oleh siswa mungkin terjadi pada saat siswa itu menyelesaikan masalah. Terdapat 2 (dua) faktor yang memengaruhi kemampuan penyelesaian masalah dalam matematika. Faktor pertama adalah faktor langsung berupa sikap siswa terhadap matematika, penghargaan terhadap diri sendiri, dan kebiasaan pendidik dalam mengajar. Faktor yang kedua adalah faktor tidak langsung berupa motivasi dan potensi siswa (Pimta, Tayruakham, \& Nuangchalerm, 2009). Salah satu faktor potensi siswa adalah jenis temperamen siswa tersebut.

Temperamen adalah kombinasi sifat-sifat bawaan yang secara tidak sadar memengaruhi semua perilaku (Lahaye, 1994). Terdapat hubungan yang erat antara jenis temperamen dengan prestasi akademik matematika (Li \& Pang, 2007). Temperamen siswa memiliki potensi untuk membentuk kualitas hubungan guru-siswa. Siswa dengan emosionalitas positif yang tinggi atau kontrol yang kuat (aspek ketekunan tugas yang berhubungan dengan kemampuan perhatian siswa) lebih cenderung memiliki hubungan guru-siswa yang dekat dan tidak banyak konflik (Collins \& O'Connor, 2016). Tulisan-tulisan tentang temperamen pertama kali dikaitkan dengan Hippocrates dan Plato. Hippocrates mengemukakan suatu teori yang mengatakan bahwa pada dasarnya ada 4 (empat) jenis temperamen dasar yang dimiliki manusia. Hippocrates memberi nama jenis temperamen tersebut sebagai sanguine, choleric, melancholic, dan phlegmatic (Safarzadeh, Soloukdar, Vavaeinia, \& Rezaeizadeh, 2013; Suryabrata, 2004). Secara umum, manusia dengan jenis temperamen sanguine adalah orang yang sangat bersemangat dalam hidupnya. la selalu tampak ceria, ramah, dan lincah. Manusia dengan jenis temperamen choleric adalah orang yang memiliki kemauan keras dalam mencapai sesuatu. la adalah orang yang aktif, agresif, optimis, dan percaya diri. Manusia dengan jenis temperamen melancholic adalah orang yang analitis dan perfeksionis, namun pemurung dan sensitif. Manusia dengan jenis temperamen phlegmatic adalah orang yang tenang dan dapat diandalkan, namun malas dan keras kepala.

Perbedaan jenis temperamen merupakan cerminan dari apa yang dipikirkan siswa. Hal ini menegaskan bahwa siswa memiliki proses penyelesaian masalah yang berbeda sesuai dengan interaksi yang terjadi 
secara internal di dalam dirinya. Interaksi internal ini nantinya dapat diamati dari adanya perbedaan temperamen yang nampak dari siswa berupa pola pikir yang bervariasi. Di dalam dunia pendidikan khususnya pembelajaran matematika, hasil pemikiran siswa dapat dilihat melalui hasil pekerjaannya dalam menyelesaikan suatu soal atau masalah matematika. Tujuan penelitian ini adalah untuk mendeskripsikan proses berpikir siswa bertemperamen choleric dan melancholic dalam menyelesaikan masalah geometri. Siswa bertemperamen choleric dipilih karena mempunyai kemauan yang keras dalam menyelesaikan masalah dan sangat percaya diri, sedangkan siswa bertemperamen melancholic dipilih karena mempunyai sifat analitis dan perfeksionis, yang sangat dibutuhkan dalam menyelesaikan masalah.

\section{B. Metode Penelitian}

Subjek dalam penelitian ini adalah 2 (dua) siswa perempuan dengan kemampuan matematika tinggi dan setara di kelas IX-A Madrasah Tsanawiyah Negeri Salatiga Tahun Pelajaran 2016/2017, dengan perincian 1 (satu) siswa bertemperamen choleric dan 1 (satu) siswa bertemperamen melancholic. Pemilihan subjek penelitian dimulai setelah siswa diberikan tes temperamen untuk menentukan jenis temperamen siswa dan diperoleh calon subjek penelitian yaitu siswa bertemperamen choleric dan siswa bertemperamen melancholic. Kemudian calon subjek penelitian diberikan tes kemampuan matematika untuk mengelompokan calon subjek penelitian berdasarkan kemampuan matematikanya yaitu kemampuan matematika tinggi, kemampuan matematika sedang, atau kemampuan matematika rendah. Subjek penelitian diperlakukan sama, yaitu diberikan tugas penyelesaian masalah dan diminta untuk menyelesaikan tugas tersebut serta diwawancarai pada waktu yang berbeda-beda. Dalam penelitian ini, dilakukan triangulasi waktu yaitu melakukan pengecekan tes tertulis dan wawancara semi terstruktur dengan subjek penelitian dan teknik yang sama tetapi dalam waktu yang berbeda, sehingga diperoleh data yang valid. Setelah data valid diperoleh, kemudian data dianalisis menggunakan 3 (tiga) tahapan, yaitu kondensasi data, penyajian data, serta penarikan kesimpulan dan verifikasi. 
Tugas penyelesain masalah geometri yang diberikan berupa 1 (satu) soal bangun datar tidak rutin yang terkait dengan segibanyak beraturan. Tugas dikerjakan oleh subjek penelitian dalam waktu maksimal 20 menit. Tugas terdiri dari 2 (dua) jenis dengan isi yang setara. Tugas digunakan untuk mendeskripsikan proses berpikir siswa bertemperamen choleric dan melancholic dalam menyelesaikan masalah geometri berdasarkan 4 (empat) tahap penyelesaian masalah, yaitu understanding the problem (memahami masalah), devising a plan (merancang rencana penyelesaian), carrying out the plan (melaksanakan rencana penyelesaian), dan looking back (memeriksa kembali) (Polya, 1973). Instrumen tugas penyelesaian masalah yang diberikan sebagai berikut.

Tabel 1. Instrumen Tugas Penyelesaian Masalah

\begin{tabular}{|l|l|}
\hline \multicolumn{1}{|c|}{ Tugas Penyelesaian Masalah 1} & Tugas Penyelesaian Masalah 2 \\
\hline Perhatikan gambar berikut. & Perhatikan gambar berikut. \\
Bangun PQRST adalah sebuah segi-5 \\
beraturan (semua sisinya sama \\
panjang dan semua sudutnya sama \\
besar). $\begin{array}{l}\text { Bangun KLMNOPQR adalah sebuah } \\
\text { segi-8 beraturan (semua sisinya } \\
\text { sama panjang dan semua sudutnya } \\
\text { sama besar). } \\
\text { garis lurus. } \\
\text { Berapakah nilai } y \text { ? terletak pada sebuah }\end{array}$ & $\begin{array}{l}\text { Titik L, M, dan S terletak pada } \\
\text { sebuah garis lurus. } \\
\text { Berapakah nilai } z \text { ? }\end{array}$ \\
\hline
\end{tabular}

Indikator berpikir konseptual dan prosedural yang digunakan dalam penelitian ini ditunjukan pada Tabel 2.

Tabel 2. Indikator Berpikir Konseptual dan Berpikir Prosedural

\begin{tabular}{|c|c|}
\hline Indikator Berpikir Konseptual & Indikator Berpikir Prosedural \\
\hline $\begin{array}{l}\text { Menggunakan Aturan Dasar } \\
\text { 1. Menunjukkan kemampuan } \\
\text { untuk menggunakan konsep } \\
\text { dasar dalam mengidentifikasi } \\
\text { dan menyelesaikan masalah. } \\
\text { 2. Menggunakan pengalaman }\end{array}$ & $\begin{array}{l}\text { 1. Menunjukkan kemampuan } \\
\text { untuk menggunakan konsep } \\
\text { dasar dalam mengidentifikasi } \\
\text { masalah. } \\
\text { 2. Menggunakan pengalaman } \\
\text { sebelumnya untuk memahami }\end{array}$ \\
\hline
\end{tabular}




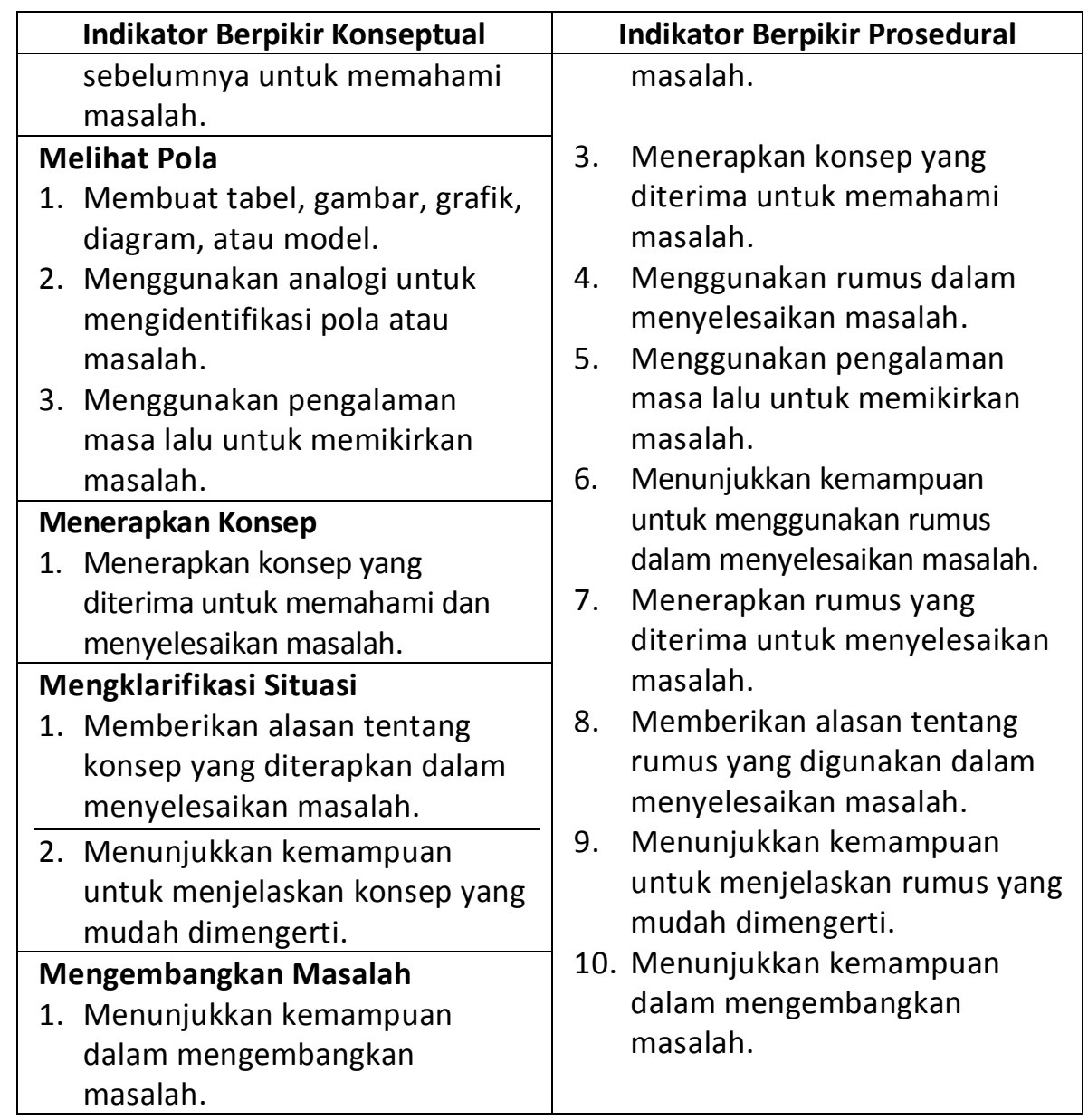

\section{Temuan dan Pembahasan}

\section{Subjek Bertemperamen Choleric}

Jawaban tertulis subjek bertemperamen choleric dalam menyelesaikan tugas penyelesaian masalah 1 sebagai berikut.

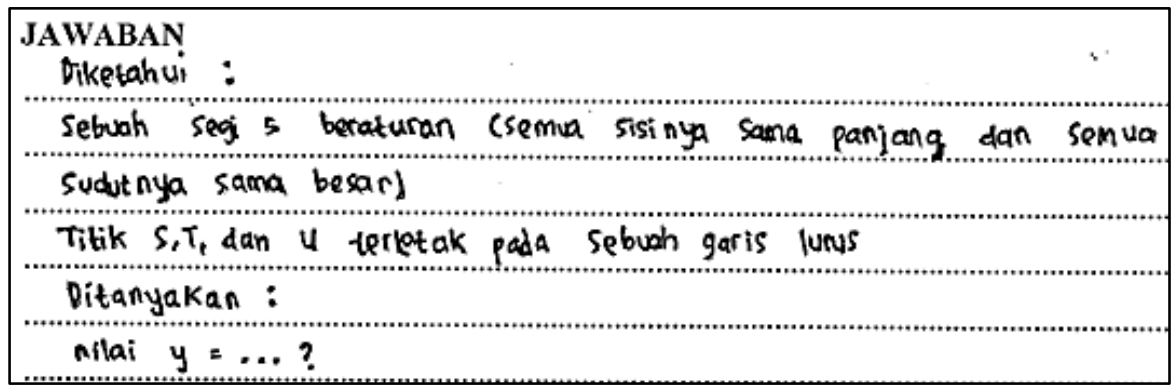




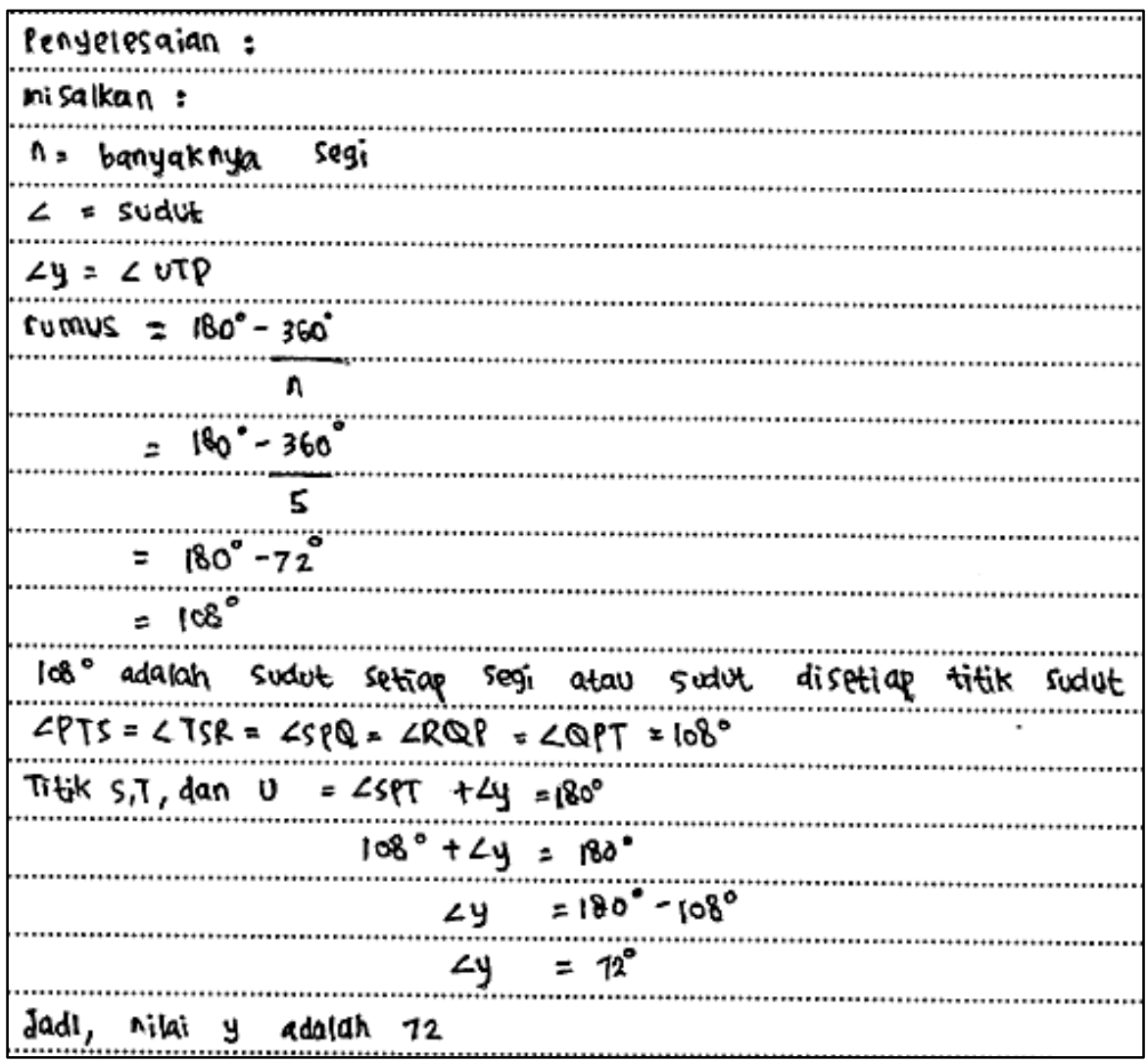

Gambar 1. Jawaban Subjek Bertemperamen Coleric dalam Menyelesaikan Tugas Penyelesaian Masalah 1

Jawaban tertulis subjek bertemperamen choleric dalam menyelesaikan tugas penyelesaian masalah 2 sebagai berikut.

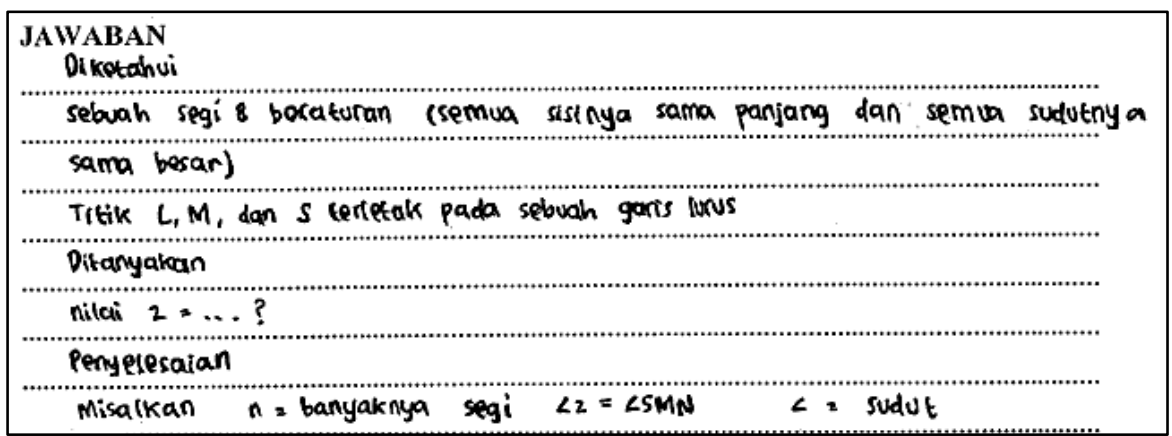




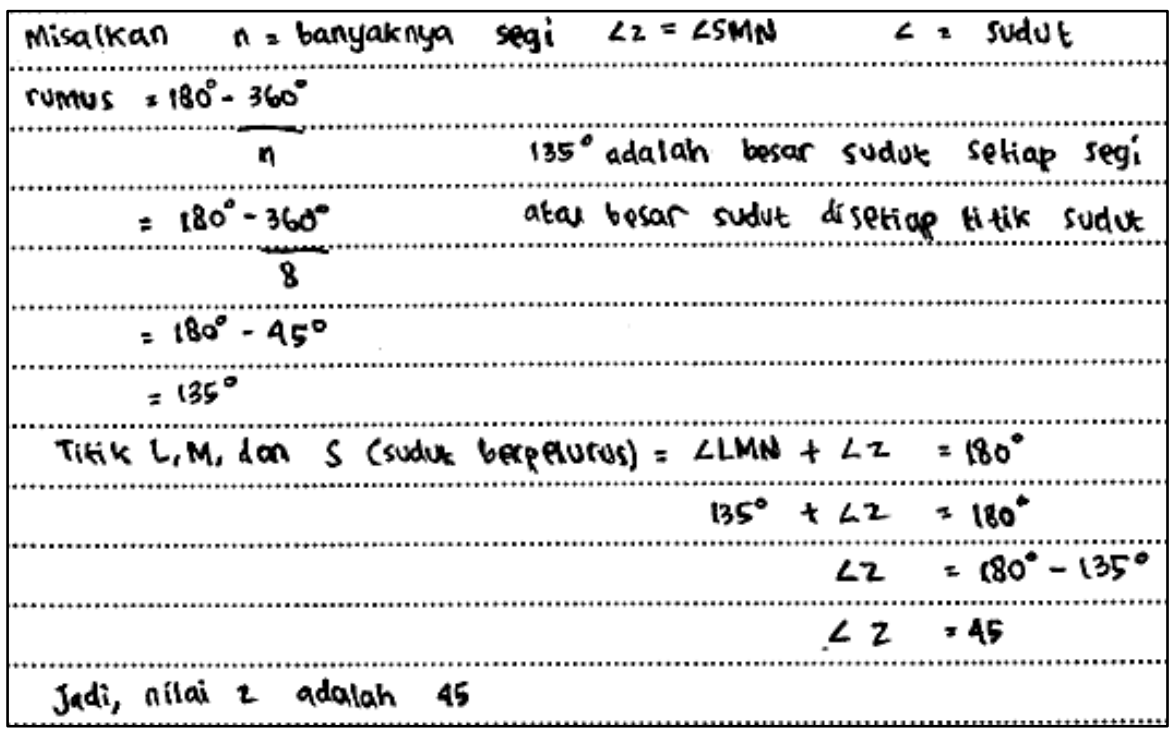

Gambar 2. Jawaban Subjek Bertemperamen Coleric dalam Menyelesaikan Tugas Penyelesaian Masalah 2

Proses berpikir subjek bertemperamen choleric sebagai berikut.

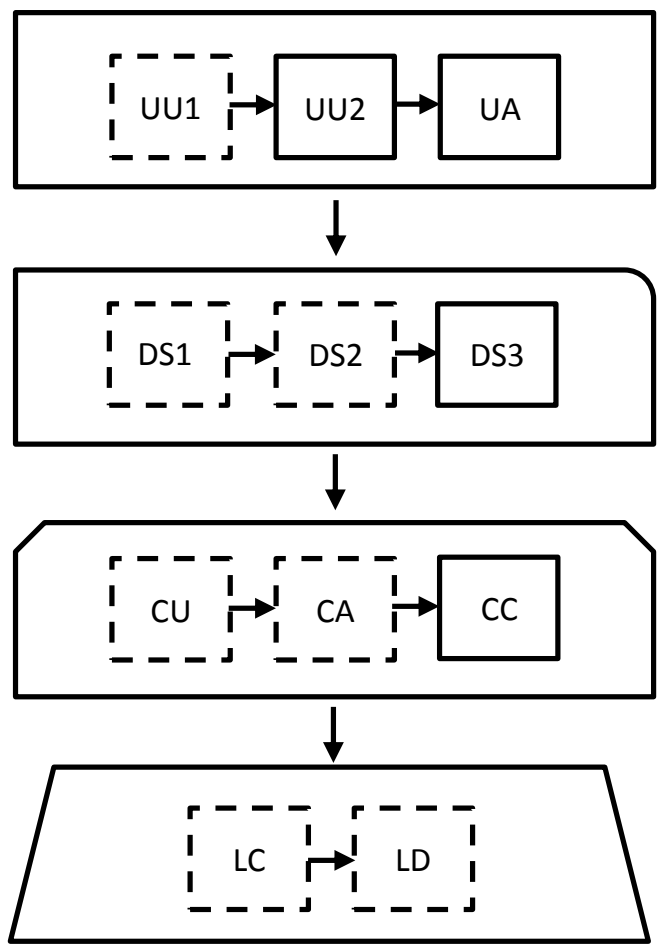




\section{Keterangan:}

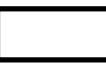

: Tahap memahami masalah

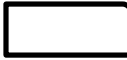

: Tahap merancang rencana penyelesaian

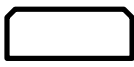

: Tahap melaksanakan rencana penyelesian

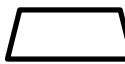

: Tahap memeriksa kembali

: $\quad$ Proses berpikir

: Tahap penyelesaian masalah

Menunjukkan kemampuan untuk menggunakan

UU1 : konsep dasar geometri dalam mengidentifikasi masalah

UU2 Menggunakan pengalaman sebelumnya untuk memahami masalah

UA

Menerapkan konsep yang diterima untuk memahami masalah

DS1 : Membuat tabel, gambar, grafik, diagram, atau model

DS2 . Menggunakan analogi untuk mengidentifikasi pola atau masalah

DS3 Menggunakan pengalaman masa lalu untuk memikirkan masalah

Menunjukkan kemampuan untuk menggunakan

CU : konsep dasar geometri dalam menyelesaikan masalah

CA $\quad$ Menerapkan konsep geometri yang diterima untuk menyelesaikan masalah

Memberikan alasan tentang konsep geometri yang

CC : diterapkan dalam menyelesaikan masalah atau memperjelas situasi

: Menunjukkan kemampuan untuk menjelaskan konsep geometri yang mudah dimengerti

LD Menunjukkan kemampuan dalam mengembangkan masalah

Gambar 3. Proses Berpikir Subjek Bertemperamen Coleric dalam Menyelesaikan Masalah Geometri

Subjek bertemperamen choleric menggunakan pengalaman sebelumnya tentang sudut untuk memahami masalah, mengaitkan informasi yang diterima dengan materi atau pengalaman terdahulu 
tentang aturan yang digunakan dalam soal, mengidentifikasi apa yang diketahui dan apa yang ditanyakan, serta mengidentifikasi informasi yang diperlukan. Hal ini sesuai dengan pendapat yang menjelaskan bahwa salah satu indikator pemahaman konsep adalah kemampuan mengembangkan syarat perlu atau syarat cukup dari suatu konsep (Kilpatrick, Swafford, \& Findell, 2001). Subjek bertemperamen choleric mengidentifikasi hubungan antara informasi yang diketahui dengan informasi yang belum diketahui dan menggunakan materi sebelumnya untuk memikirkan masalah.

Subjek bertemperamen choleric memilih strategi penyelesaian masalah menggunakan rumus untuk mencari ukuran sudut luar segibanyak beraturan, yaitu $180-\frac{360}{n}, n=$ banyaknya sisi dari segibanyak beraturan, dengan tepat dan tidak menggunakan analogi untuk mengidentifikasi pola atau masalah. Hal ini sesuai dengan penelitian lain yang menyimpulkan bahwa seorang siswa dinyatakan telah memahami rumus jika ia dapat menggunakan rumus pada situasi yang tepat (Shadiq, 2008). Subjek bertemperamen choleric menjelaskan langkah penyelesaian yang diberikan dan memberikan alasan tentang konsep geometri yang digunakan dalam menyelesaikan masalah. Subjek menunjukkan kemampuan dalam mengembangkan masalah. Subjek bertemperamen choleric menggunakan proses berpikir prosedural dalam menyelesaikan masalah geometri tentang sudut luar segibanyak beraturan, yaitu menyelesaikan masalah menggunakan rumus.

\section{Subjek Bertemperamen Melancholic}

Jawaban tertulis subjek bertemperamen melanholic dalam menyelesaikan tugas penyelesaian masalah 1 sebagai berikut.

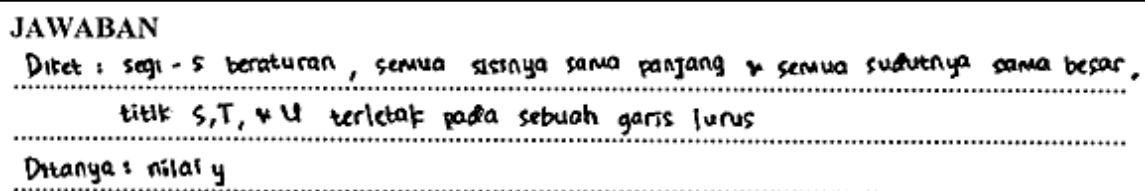




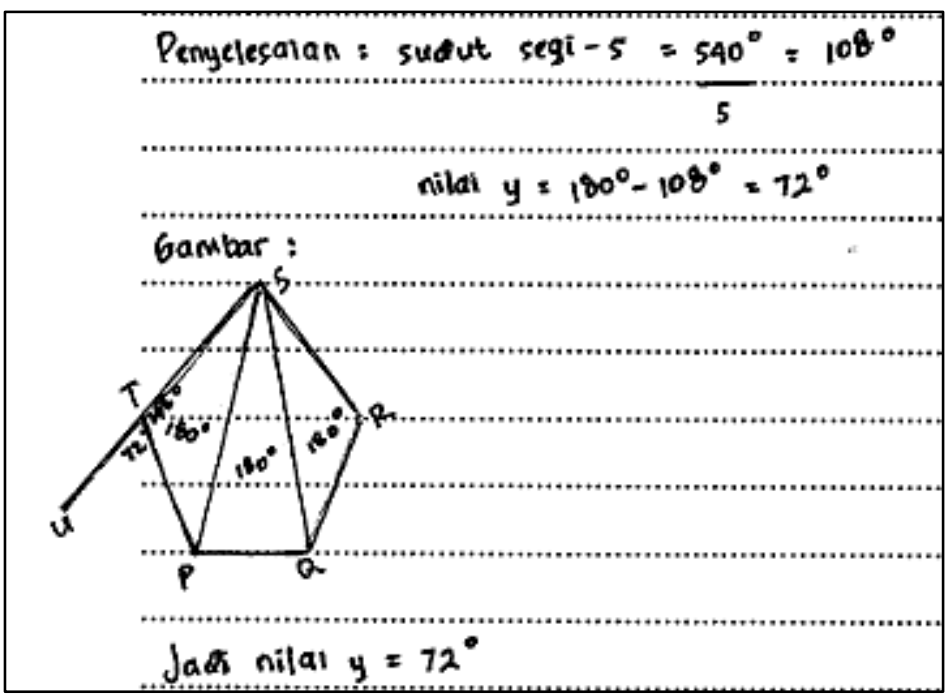

Gambar 4. Jawaban Subjek Bertemperamen Melancholic dalam Menyelesaikan Tugas Penyelesaian Masalah 1

Jawaban tertulis subjek bertemperamen melanholic dalam menyelesaikan tugas penyelesaian masalah 2 sebagai berikut.

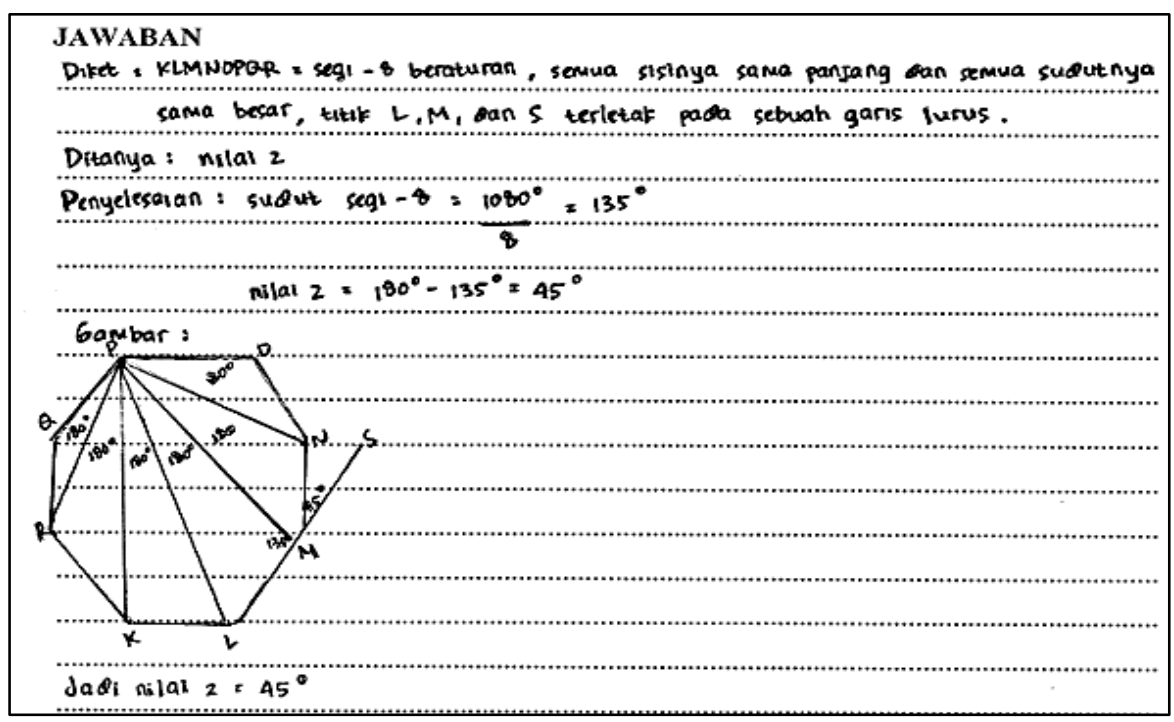

Gambar 5. Jawaban Subjek Bertemperamen Melancholic dalam Menyelesaikan Tugas Penyelesaian Masalah 2 
Proses berpikir subjek bertemperamen melancholic sebagai berikut.

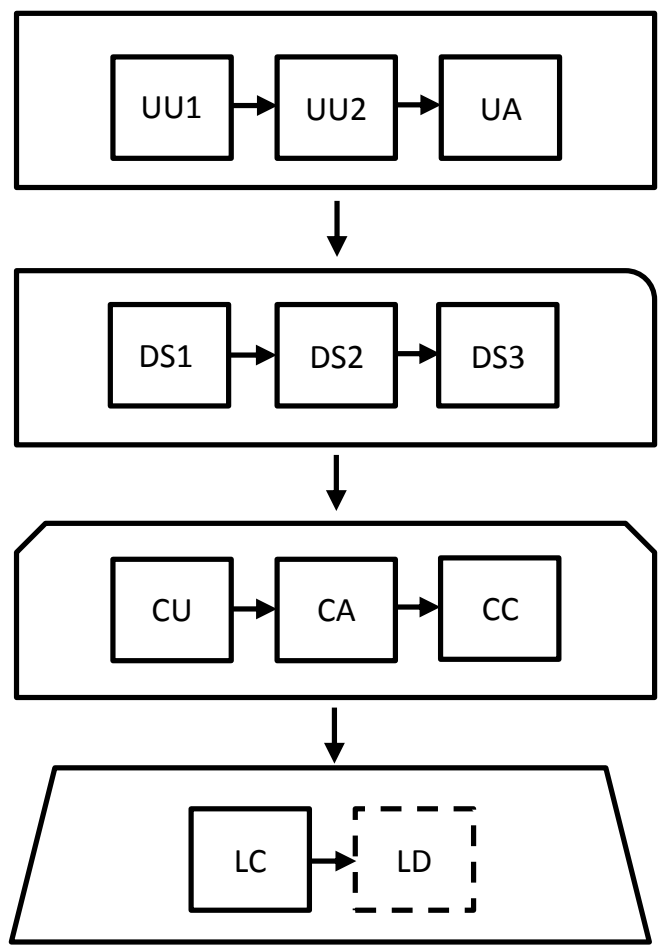

\section{Keterangan:}

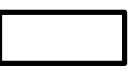

: Tahap memahami masalah

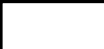

: Tahap merancang rencana penyelesaian

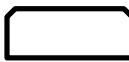

: Tahap melaksanakan rencana penyelesian

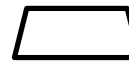

: Tahap memeriksa kembali

: $\quad$ Proses berpikir

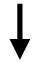

: Tahap penyelesaian masalah

Menunjukkan kemampuan untuk menggunakan

UU1 : konsep dasar geometri dalam mengidentifikasi masalah

UU2

UA

: Menerapkan konsep yang diterima untuk memahami 


\begin{tabular}{|c|c|c|}
\hline & & masalah \\
\hline DS1 & $:$ & Membuat tabel, gambar, grafik, diagram, atau model \\
\hline S2 & $:$ & $\begin{array}{l}\text { Menggunakan analogi untuk mengidentifikasi pola } \\
\text { atau masalah }\end{array}$ \\
\hline S3 & $:$ & $\begin{array}{l}\text { Menggunakan pengalaman masa lalu untuk } \\
\text { memikirkan masalah }\end{array}$ \\
\hline CU & : & $\begin{array}{l}\text { Menunjukkan kemampuan untuk menggunakan } \\
\text { konsep dasar geometri dalam menyelesaikan } \\
\text { masalah }\end{array}$ \\
\hline CA & : & $\begin{array}{l}\text { Menerapkan konsep geometri yang diterima untuk } \\
\text { menyelesaikan masalah }\end{array}$ \\
\hline CC & : & $\begin{array}{l}\text { Memberikan alasan tentang konsep geometri yang } \\
\text { diterapkan dalam menyelesaikan masalah atau } \\
\text { memperjelas situasi }\end{array}$ \\
\hline LC & : & $\begin{array}{l}\text { Menunjukkan kemampuan untuk menjelaskan } \\
\text { konsep geometri yang mudah dimengerti }\end{array}$ \\
\hline LD & $:$ & $\begin{array}{l}\text { Menunjukkan kemampuan dalam mengembangkan } \\
\text { masalah }\end{array}$ \\
\hline
\end{tabular}

Gambar 6. Proses Berpikir Subjek Bertemperamen Melancholic dalam Menyelesaikan Masalah Geometri

Subjek bertemperamen melancholic menggunakan konsep dasar geometri dalam mengidentifikasi dan menyelesaikan masalah. Subjek menyebutkan unsur-unsur segibanyak beraturan dengan lengkap (titik sudut, sisi, dan diagonal). Subjek menggunakan pengalaman sebelumnya tentang sudut untuk memahami masalah. Subjek mengaitkan informasi yang diterima dengan materi atau pengalaman terdahulu tentang aturan yang digunakan dalam soal, yaitu aturan tentang sudut berpelurus dan mengidentifikasi aturan tentang sudut lainnya (berpenyiku). Subjek mengidentifikasi apa yang diketahui dan apa yang ditanyakan dan mengidentifikasi informasi yang diperlukan.

Subjek bertemperamen melancholic melihat pola dengan terlebih dahulu membuat gambar sketsa segibanyak beraturan untuk mempermudah penyelesaian masalah. Subjek memilih strategi penyelesaian masalah menggunakan vertex method untuk mencari ukuran sudut luar segibanyak beraturan dengan tepat dan tidak menggunakan analogi untuk mengidentifikasi pola atau masalah. Subjek menggambar garis-garis dari titik sudut ke titik sudut lainnya, sehingga segibanyak 
beraturan terbagi menjadi beberapa segitiga. Subjek memilih untuk menggambar garis dari satu titik sudut, sehingga pola yang terbentuk menjadi tepat. Hal ini sesuai dengan pendapat yang menyatakan bahwa matematika adalah ilmu pola dan hubungan yang berkaitan dengan kuantitas (James Cook University Australia, 2007). Subjek menggunakan analogi yang tepat untuk mengidentifikasi pola atau masalah yang diberikan. Subjek menggunakan pengalaman masa lalu dan ide sendiri untuk memikirkan masalah yang diberikan. Subjek mengidentifikasi hubungan antara informasi yang diketahui dengan informasi yang belum diketahui.

Subjek bertemperamen melancholic menerapkan konsep geometri yang diterima untuk memahami dan menyelesaikan masalah dengan menjelaskan langkah penyelesaian yang diberikan. Subjek menggunakan aturan tentang sudut berpelurus dan pengetahuan atau materi sebelumnya tentang operasi hitung dalam menyelesaikan masalah.

Subjek bertemperamen melancholic mengklarifikasi situasi dengan memberikan alasan tentang konsep geometri yang digunakan dalam menyelesaikan masalah, yaitu agar mudah dalam menyelesaikan soal yang diberikan. Hal ini sesuai dengan pendapat yang menyatakan bahwa alasan matematis, formal atau tidak, perlu dimasukkan dalam konteks yang benar seperti halnya pengetahuan manusia lainnya (Van Bendegem \& Van Kherkhove, 2009). Subjek menunjukkan kemampuan untuk menjelaskan konsep geometri tentang vertex method yang mudah dimengerti. Hal ini terlihat dari penjelasan subjek tentang langkah-langkah penyelesaian yang digunakan.

Subjek bertemperamen melancholic tidak menguasai 1 (satu) kompetensi proses berpikir konseptual, yaitu mengembangkan masalah. Subjek tidak menunjukkan kemampuan untuk mengembangkan soal menjadi soal yang baru. Subjek bertemperamen melancholic telah menggunakan proses berpikir konseptual dalam menyelesaikan masalah geometri tentang sudut luar segibanyak beraturan, yaitu menyelesaikan masalah menggunakan vertex method.

Tabel 3. Perbedaan Proses Berpikir Subjek Bertemperamen Choleric dengan Subjek Bertemperamen Melancholic dalam Menyelesaikan Masalah Geometri 


\begin{tabular}{|c|c|}
\hline $\begin{array}{c}\text { Proses Berpikir Subjek } \\
\text { Bertemperamen Choleric }\end{array}$ & $\begin{array}{c}\text { Proses Berpikir Subjek } \\
\text { Bertemperamen Melancholic }\end{array}$ \\
\hline $\begin{array}{l}\text { Tidak lengkap dalam menyebutkan } \\
\text { unsur-unsur segibanyak beraturan }\end{array}$ & $\begin{array}{l}\text { Lengkap dalam menyebutkan unsur- } \\
\text { unsur segibanyak beraturan }\end{array}$ \\
\hline Menggunakan rumus & Membuat gambar sketsa \\
\hline $\begin{array}{l}\text { Tidak menggunakan analogi untuk } \\
\text { mengidentifikasi pola atau masalah }\end{array}$ & $\begin{array}{l}\text { Menggunakan analogi yang tepat } \\
\text { untuk mengidentifikasi pola atau } \\
\text { masalah }\end{array}$ \\
\hline $\begin{array}{l}\text { Memberikan alasan tentang konsep } \\
\text { geometri yang digunakan dalam } \\
\text { menyelesaikan masalah dengan } \\
\text { mengatakan bahwa ada rumus yang } \\
\text { bisa dipakai dalam menyelesaikan } \\
\text { soal }\end{array}$ & $\begin{array}{l}\text { Memberikan alasan tentang konsep } \\
\text { geometri yang digunakan dalam } \\
\text { menyelesaikan masalah dengan } \\
\text { mengatakan agar mudah dalam } \\
\text { menyelesaikan masalah yang } \\
\text { diberikan }\end{array}$ \\
\hline $\begin{array}{l}\text { Menunjukkan kemampuan dalam } \\
\text { mengembangkan masalah }\end{array}$ & $\begin{array}{l}\text { Tidak menunjukkan kemampuan } \\
\text { dalam mengembangkan masalah }\end{array}$ \\
\hline
\end{tabular}

\section{Simpulan}

Berdasarkan hasil penelitian, dapat disimpulkan bahwa proses berpikir terungkap melalui tugas penyelesaian masalah yang diberikan. Siswa bertemperamen choleric menunjukkan kemampuan untuk menggunakan konsep titik sudut dan sisi bangun datar dalam mengidentifikasi masalah. Siswa menggunakan pengalaman belajar tentang sudut berpelurus untuk memahami masalah. Siswa bertemperamen choleric memilih strategi penyelesaian masalah menggunakan rumus $180-\frac{360}{n}$. Siswa tidak menggunakan analogi untuk mengidentifikasi masalah. Siswa menggunakan pengalaman menerapkan rumus untuk memikirkan masalah. Siswa bertemperamen choleric menggunakan proses berpikir prosedural dalam menyelesaikan masalah geometri.

Siswa bertemperamen melancholic menggunakan aturan dasar dengan menunjukkan kemampuan untuk menggunakan konsep titik sudut, sisi, dan diagonal bangun datar dalam mengidentifikasi masalah. Siswa menggunakan pengalaman belajar tentang sudut berpenyiku dan berpelurus untuk memahami masalah. Siswa bertemperamen melancholic melihat pola dengan menggunakan analogi yang tepat untuk mengidentifikasi masalah. Siswa bertemperamen melancholic memilih 
strategi penyelesaian masalah menggunakan vertex method. Siswa menggunakan pengalaman bangun datar dan sudut untuk melihat pola dan memikirkan masalah. Siswa bertemperamen melancholic menerapkan konsep geometri yang diterima dengan menggunakan aturan tentang sudut berpelurus dan pengetahuan atau materi sebelumnya tentang operasi hitung dalam menyelesaikan masalah. Siswa bertemperamen melancholic mengklarifikasi situasi dengan memberikan alasan tentang konsep geometri yang digunakan dalam menyelesaikan masalah atau memperjelas situasi, yaitu agar mudah dalam menyelesaikan soal yang diberikan dan menunjukkan kemampuan untuk menjelaskan konsep geometri yang mudah dimengerti. Siswa bertemperamen melancholic tidak menguasai 1 (satu) kompetensi proses berpikir konseptual, yaitu mengembangkan masalah. Siswa bertemperamen melancholic menggunakan proses berpikir konseptual dalam menyelesaikan masalah geometri.

Berdasarkan hasil penelitian, dapat dikemukakan saran untuk guru agar senantiasa merancang kegiatan pembelajaran yang dapat membentuk pemikiran konseptual siswa melalui penanaman konsepkonsep matematika dibandingkan dengan kegiatan pembelajaran yang hanya dapat membentuk pemikiran prosedural siswa.

\section{Ucapan Terima Kasih}

Saya mengucapkan terima kasih kepada Ketua Program Studi Pendidikan Matematika Pascasarjana Universitas Negeri Surabaya, Wakil Dekan III Fakutas MIPA Universitas Negeri Surabaya, dan Kepala Madrasah Tsanawiyah Negeri Salatiga.

\section{Daftar Pustaka}

Abdillah, S. H. (2007). Conceptual thinking. Sabah: Institut Latihan Sektor Awam Negeri.

Avcu, S., \& Avcu, R. (2010). Pre-service elementary mathematics teachers' use of strategies in mathematical problem solving. Procedia Social and Behavioral Sciences, 9(2010), 1282-1286. 
Aydogdu, M. Z., \& Kesan, C. (2014). A research on geometry problem solving strategies used by elementary mathematics teacher candidates. Journal of Educational and Instructional Studies in the World, 4(1), 53-62.

Clements, D. H., \& Sarama, J. (2000). Young Children's Ideas about. Retrieved from www.nctm.org

Collins, A., \& O'Connor, E. (2016). Teacher-child relationships and child temperament in early achievement. Journal of Educational and Developmental Psychology, 6(1), 173-194.

Duron, R., Limbach, B., \& Waugh, W. (2006). Critical thinking framework for any discipline. International Journal of Teaching and Learning in Higher Education, 17(2), 160-166.

Government of Canada. (2015). Conceptual thinking. Ontario: National Research Council Canada.

Hamda. (2016). Berpikir Konseptual dalam Pemecahan Masalah Matematika dan Implikasinya dalam Kehidupan Nyata. Prosiding Seminar Nasional, (pp. 22 - 30). Palopo.

James Cook University Australia. (2007). Maths module 1 an introduction to mathematics. Brisbane: James Cook University Australia.

Kementerian Pendidikan dan Kebudayaan Republik Indonesia. (2013). Lampiran Peraturan Menteri Pendidikan dan Kebudayaan Nomor 68 Tahun 2013 tentang Kerangka Dasar dan Struktur Kurikulum Sekolah Menengah Pertama/Madrasah Tsanawiyah. Kerangka Dasar dan Struktur Kurikulum Sekolah Menengah Pertama/Madrasah Tsanawiyah. Jakarta, Daerah Khusus Ibukota Jakarta, Indonesia: Kementerian Pendidikan dan Kebudayaan Republik Indonesia.

Kilpatrick, J., Swafford, J., \& Findell, B. (2001). Adding it up: Helping children learn mathematics. Washington: National Academy Press.

Lahaye, T. (1994). Temperament. In Spirit-Controlled Temperament (pp. 1-4). Illinois: Tyndale House Publishers, Inc.

Li, M., \& Pang, K. (2007). A study on the relationship between temperament and mathematics academic achievement. Journal of the Korea Society of Mathematical Education, 11(3), 197-207.

Pimta, S., Tayruakham, S., \& Nuangchalerm, P. (2009). Factors influencing mathematic problem-solving ability of sixth grade students. Journal of Sciences, 5(4), 381-385.

Polya, G. (1973). How to solve it: A new aspect of mathematical method. Princeton: Princeton University Press.

Pusat Penilain Pendidikan Republik Indonesia. (2015). Laporan Hasil Ujian Nasional. (Badan Standar Nasional Pendidikan) Retrieved May 31, 2016, from Laporan Hasil Ujian Nasional: http://118.98.234.50//hun/daya_serap.aspx

Safarzadeh, H., Soloukdar, A., Vavaeinia, M., \& Rezaeizadeh, H. (2013). Studying the effects of organizational personality traits on different 
human temperaments based on the five-factor model of personality. Caspian Journal of Applied Sciences Research, 2(3), 146-162.

Schunk, D. H. (2012). Learning theories: An educational perspective. Boston: Pearson Education, Inc.

Shadiq, F. (2008, December 19). Empat Objek Langsung Matematika Menurut Gagne. Retrieved from fadjarp3g Situsnya Guru Matematika: https://fadjarp3g.files.wordpress.com/2008/12/download_08_gagne_me dian_1.pdf

Suryabrata, S. (2004). Psikologi Pendidikan. Jakarta: PT Rajagrafindo Persada.

Van Bendegem, J. P., \& Van Kherkhove, B. (2009). Mathematical arguments in context. Foundations of Science, 14(1-2), 1-18. 